\title{
POLA INTERAKSI MASYARAKAT BANGSAWAN DENGAN NON BANGSAWAN DI DESA SAKRA KABUPATEN LOMBOK TIMUR \\ ${ }^{1}$ Srianti \\ ${ }^{1}$ MAN 1 Lombok Timur \\ Srianti47@yahoo.com
}

\begin{abstract}
This study aims to determine the patterns of interaction, customs, language and behavior of nobles and non-nobles in Sakra village. The research method used in this study is the phenomenology method. Data collection by observation, interviews, and documentation. The data collected in this study is data about the patterns of interaction of the Sakra Village community. The results of this study indicate that in Sakra Village there are two distinct groups of social identities known as aristocrats (perwangse) and non-aristocrats (jajarkarang). As for this group of perwangse, there are those who are native nobles and immigrant nobles. These two different social groups have different identities both in language, customs, marriage system, social status and others. The perwangse group has a higher social status than jajar coral, and of course its identity is also different. But over time because several factors such as education, economics, and social status of the high nobility experienced a shift and a kind of cultural erosion. So it can be concluded that the nobility in Sakra Village was once the most influential social group, but because of several declining status factors or in short there has been a cultural shift and kinship system in the Sakra Village community.
\end{abstract}

Keywords: Nobility, Patterns of Interaction, Society.

\begin{abstract}
ABSTRAK
Penelitian ini bertujuan untuk mengetahui pola interaksi, adat istiadat, bahasa dan tingkah laku bangsawan dan non bangsawan di desa Sakra. Metode penelitian yang digunakan dalam penelitian ini adalah metode fenomenologi. Pengumpulan data dengan cara observasi, wawancara, dan dokumentasi. Data yang dikumpulkan dalam penelitian ini adalah data tentang pola interaksi masyarakat Desa Sakra. Hasil penelitian ini menunjukkan bahwa Di Desa Sakra terdapat dua golongan yang berbeda identitas sosial yang dikenal dengan golongan bangsawan (perwangse) dan non bangsawan (jajarkarang). Adapun golongan perwangse ini, ada yang merupakan bangsawan asli dan bangsawan pendatang. Dari kedua golongan sosial yang berbeda ini memiliki identitas yang berbeda pula baik dalam bahasa, adat-istiadat, sistem perkawinan, status sosial dan lain-lain. Golongan perwangse memiliki status sosial yang lebih tinggi daripada jajar karang ,dan sudah barang tentu identitasnya juga berbeda. Namun seiring berjalannya waktu karena beberapa faktor seperti pendidikan, ekonomi, maupun sosial kemasyarakatan status bangsawan yang tinggi tersebut mengalami pergeseran dan terjadinya semacam erosi budaya. Jadi dapat disimpulkan bahwa golongan bangsawan di Desa Sakra pernah menjadi golongan sosial yang paling berpengaruh, namun karena beberapa faktor statusnya menurun atau singkatnya telah terjadi pergeseran budaya dan sistem kekerabatan pada masyarakat Desa Sakra.
\end{abstract}

Kata Kunci: Pola Interaksi, Masyarakat, Bangsawan 


\section{PENDAHULUAN}

Manusia sebagai individu maupun sebagai masyarakat merupakan bagian yang sangat kompleks untuk dibicarakan, karena seperti yang kita ketahuai bahwa suatu masyarakat mempunyai bentuk-bentuk struktur sosial, seperti kelompok-kelompok sosial, kebudayaan, lembaga sosial, stratifikasi sosial, kekuasaan dan lain sebagainya. Akan tetapi, semua itu mempunyai derajat yang berbeda dalam beberapa aspek sosial di atas yang menyebabkan pola perilaku, adat istiadat maupun budaya masyarakat yang berbeda.

Bentuk umum proses sosial adalah interaksi sosial, karena interaksi sosial merupakan syarat uatama terjadinya aktivitas-aktivitas sosial. Bentuk lain proses sosial hanya merupakan bentuk-bentuk khusus dari interaksi sosial. Interaksi sosial merupakan hubungan-hubungan dinamis yang menyangkut hubungan antara orang-perorangan, antara kelompok-kelompok manusia, maupun anatara orang perorangan dengan kelompok manusia. Salah satu struktur sosial di masyarakat adalah stratifikasi sosial di mana keberadaannya menjadi bagian yang tidak kalah pentingnya dalam sejarah kehidupan manusia yaitu adanya golongan atas, golongan menengah, dan kelas menengah (Soekanto, 2012: 62).

Namun, setidaknya masyarakat yang pernah mengembangkan sistem ini karena tidak ada ukuran yang membedakan secara ketat dalam setiap golongan. Maka bisa dikatakan mulai sejak kedatangan Islam, masuknnya imperialism barat sampai saat ini, baik pada masyarakat non bangsawan maupun masyarakat bangsawan pada khususnya. Oleh sebab itu golongan bangsawan bukan menjadi ukuran bahwa seseorang itu mempunyai derajat yang tinggi, namun kemampuan seseoranglah yang bisa membuat derajat berubah.

Adanya interaksi sosial ini terdapat hampir di semua lapisan masyarakat. Secara tidak sadar hal tersebut ada, namun keberadaannya tidak terdapat pada masyarakat antara orang-perorang, kelompok-kelompok, dan golongan-golongan yang menimbulkan interaksi sosial. Di Indonesia juga terdapat pelapisan sosial tersebut namun keberadaannya masih ada toleransi dengan tingakat di bawahnya. Adapun wilayah yang masih eksis dengan pelapisan sosial tersebut diantaranya, Jawa, Yogjakarta, Sulawesi dan lainnya. Dengan adanya pengaruh dari Jawa, sistem 
perkawinan seperti selarian yang ada di Lombok pada umumnya. Lambat laun bergeser menjadi sistem meminang (pelamaran). Akan tetapi yang difokuskan dalam penelitian ini adalah pola interaksi masyarakat bangsawan dengan masyarakat non bangsawan.

Di Nusa Tenggara Barat (NTB) pernah berdiri beberapa kerajaan sebagai tolak ukur dalam status sosial, seperti Kerajaan Selaparang, Kerajaan Pejanggik, Kerajaan Langko, Kerajaan Pujut, Kerajaan Pene, dan lain sebagainya, masih menyisihkan adanya bukti sejarah tentang interaksi sosial yang masih nampak ditambah lagi dengan adanya pengaruh Kerajaan Karang Asem Bali. Adanya berbagai kerajaan di atas, sudah membuktikan suatu lapisan sosial sehingga timbulnya golongan bangsawan yang melaksanakan suatu adat istiadat, bahasa bahkan tingkah laku dengan golongannya. Sehingga di Nusa Tenggara Barat pada khususnya di Lombok Timur terdapat golongan bangsawan yang masih melaksanakan adat istiadat, bahasa bahkan tingkah laku dengannya, yang membedakan dengan golongan non bangsawan, yakni salah satunya di Desa Sakra.

Salah satu perbedaan dalam pola interaksi antara masyarakat bangsawan dengan non bangsawan disini seperti dalam hal adat istiadat, dimana golongan bangsawan memiliki tata cara sopan santun dalam bergaul atau berinteraksi dibandingkan dengan golongan non bangsawan yang tidak memiliki sopan santun dalam bergaul atau berinteraksi dengan baik. Dismaping itu pula golongan bangsawan memiliki bahasa yang halus, misalnya golongan bangsawan mengatakan (ya) bahasanya (nggih), (sudah) bahasanya (sampun) dan sebagainya. Sedangkan golongan non bangsawan menggunakan bahasa kasar, jika mereka mengatakan (ya) bahasanya (aok), (sudah) bahasanya (uah) dan sebagainya.

Gelar Raden, Lalu sebutan bagi laki-laki, sedangkan Baiq, Dende dan Lale sebutan bagi perempuan merupakan gelar bangsawan di Lombok. Gelar yang disebut ini merupakan rumpun status sosial yang lebih tinggi dibandingkan dengan golongan yang lainnya, seperti Amaq sebutan daripada lak-laki yang lebih tua, dan Inaq sebutan daripada perempuan yang lebih tua, gelar tersebut merupakan penyebutan daripada golongan non bangsawan. ini perlu dikaji bukan untuk membahas masalah interaksinya itu saja, namun yang penting di sini juga karena adanya adat-istiadat, bahasa (tutur kata), dalam bermasyarakat, yakni apakah masih ada pola interaksi masyarakat 
bangsawan dengan non bangsawan, serta bagaimana bentuk hubungannya. Seperti yang disampaikan Widjaya bahwa suatu bentuk proses perubahan sosial dari kebudayaan yang terwujud dalam masyarakat yang berkebudayaan primitif maupun maju, yaitu adanya proses peniruan (imitasi) yang dilakukan oleh generasi muda terhadap generasi yang lebih tua, hal tersebut dengan belajar mencari apa yang dilihat (Widjaya, 1985 : 106).

Dari penjabaran di atas dapat disimpulkan bahwa pola interaksi antara masyarakat bangsawan dengan non bangsawan yang dapat membedakannya adalah dari adatistiadat, bahasa dan tingkah laku yang dipergunakan dalam berinteraksi sehari-hari, karena golongan bangsawan memiliki derajat yang tinggi dan di hormati serta dapat dijadikan tauladan atau panutan bagi semua orang yakni golongan non bangsawan.

\section{Metode Penelitian}

Penelitian ini akan mengkaji tentang sistem kekerabatan masyarakat di Desa Sakra, maka dengan demikian data-data yang akan dikumpulkan dalam penelitian ini berupa dokumen-dokumen tertulis, informasi kejadian-kejadian Maka dalam penelitian ini peneliti menggunakan pendekatan kualitatif. Pendekatan kualitatif pada umummnya merupakan pendekatan yang menggambarkan tentang masalah status manusia, suatu obyek, suatu kondisi, suatu sistem pemikiran atau suatu kelas peristiwa pada masa sekarang (Moleong, 2005: 4).

Metode penelitian yang digunakan dalam penelitian ini adalah metode fenomenologi. Dalam metode fenomenologi peneliti mencoba menjelaskan atau mengungkap makna konsep atau fenomena pengalaman yang didasari oleh kesadaran yang terjadi pada beberapa individu. Penelitian ini dilakukan dalam situasi yang alami, sehingga tidak ada batasan dalam memaknai atau memahami fenomena yang dikaji (Creswell 1998: 54). Pengertian yang lebih khusus, sebagaimana dikemukakan oleh Craswell dalam memaknai fenomenologi dalam konsep epoche adalah membedakan wilayah data (subjek) dengan interpretasi peneliti. Konsep epoche menjadi pusat dimana peneliti menyusun dan mengelompokkan dugaan awal tentang fenomena untuk mengerti tentang apa yang dikatakan oleh responden. Alasan peneliti menggunakan metode fenomenologi karena dalam penelitian ini mengkaji tentang interaksi pada 
golongan (masyarakat) bangsawan, apakah ada perubahan dalam bahasa, tingkah laku sehari-hari yang digunakan.

\section{Hasil dan Pembahasan}

\section{Pola Interaksi Masyarakat Bangsawan dengan Bangsawan}

Dalam hal pergaulan atau interaksi antara masyarakat bangsawan dan non bangsawan di desa sakra, ada beberapa perbedaan yang bisa dilihat misalnya dari tingkatan bahasa dan adat istiadat dimana yang tua lebih dihormati dibandingkan dengan yang muda, Akan tetapi tidak menutup kemungkinan yang tua juga menghormati yang muda.

a. Pengelingsir dengan pengelingsir

Interaksi pengelinsir dengan pengelingsir bisa dilihat dari contoh percakapan Lalu Yusuf dengan Lalu Kadarul dirumah Lalu Yusuf. Disini Lalu Kadarul mengucapkan salam seraya menundukkan kepalanya semasih berada di depan pintu. Pada saat dijawab salamnya oleh Lalu Yusuf, maka Lalu Kadarul dipersilahkan masuk. Setelah masuk Lalu Kadarul mengatakan "Ampurayan gawen tiang dateng, tiang tunas gadingan tambah”. Kemudian Lalu Yusuf mengambilkan tambah (cangkul) seraya berkata "Ape yak tetambah, mbe dek taok ngadu”. Lalu Kadarul pun menjawab “Tiang nambah nike bangket sengak tiang talet ambon".

b. Pengelingsir dengan yang lebih muda

Percakapan antara Lalu Aji dengan Lalu Daham yang berada di rumahnya Lalu Aji, Lalu Aji bertetangga dengan Lalu Daham dapat di lihat dalam interaksi kesehariannya. Ketika Lalu Aji memperbaiki rumahnya yang rusak, Lalu Daham saat itu ingin keluar untuk bekerja. Tetapi Lalu Daham tidak jadi pergi, namun Lalu Daham membantu Lalu Aji untuk memperbaiki rumah seraya berkata "Maaf adik, tiang ndek taok lamun baleside bedah atep". Kemudian Lalu Aji "Angkak iyen gare-gare tiang sampun pelewas manuk sak arak lek atep bale, mangkin atep bale jari bedah”. Lalu Daham "Nggih silak tebareng-bareng kerisak, laguk sampun arak peralatan niki?. Lalu Aji "nggih" sambil memberikan palu dan paku.

c. Percakapan Ayah dengan Anaknya (keluarga) 
percakapan Lalu Sulaiman dengan keluarga istri dan anaknya ketika sedang duduk bersama di ruang tamu. Pada saat itu Lalu Sulaiman dan istrinya sedang memberitahu dan menasehati anaknya tentang tata cara serta adat-istiadat yang berlaku dikalangan keluarganya. Lalu Sulaiman mengatakan "Gawen mamik kumpulan pelinggih kance inak niki, mamik eak bebadak lamun zaman mangkin berbeda kance zaman mamik laek". Lalu Riki "Nunasan mamik napi taok bede zaman laek kance zaman mangkin”. Lalu Sulaiman "Bede niki, lamun zaman laek keluarge mamik sangat dihormati dan disanjung oleh masyarakat (golongan non bangsawan) dikarenakan mamik kance ninik laki maupun ninik bini ramah, sopan, santun. Karena bahasa sak tekadu niki teparan bahasa halus sasak sak tekadu di golongan keluarga bangsawan (mamik) adat-istiadat sak tekadu niki dalem golongan bangsawan sesuai kance agama, sak sampun teajah isik baginde Rasulullah SAW. Lamun mangkin loek golongan bangsawan sak ndek jauk atau tegawek adat-istiadat sesuai sikap kance adat kebiasaan golongan bangsawan sak tetu-tetu langan toak laek, sehingge golongan bangsawan marak niki iye teparan sedak kebangsawanan sak langan dengan toak laek, sehingga mamik kance inak berharep pelinggih adek sak dendek tepengaruh isik perkembangan zaman, lamun pelinggih gawek adat-istiadat, bahasa sak sesuai langan mamik Insya Allah pelinggih kance keluarge mamik tetep tehormati, kance tesanjung isik masyarakat (keluarge sak arak niki keluarge pelinggih maupun keluarge sak lainan)". Lalu Riki "Nggih mamik, inak tiang gawek nasehat ajaran sesuai adat-istiadat sak berlaku langan golongan bangsawan niki”. Baiq Musni “Terima kasih sanak, tiang kance mamik mangkin lalo nike pegedengan bape Rus, dendek rase laik lamun mamik ndekman olek". Lalu Riki "Nggih mamik, salam tiang tipak bape Rus, tunasin tiang kepeng”. Lalu Sulaiman “Insya Allah, nggih silak tiang lalo. Assalamu alaikum”.

Masyarakat bangsawan sering melakukan pertemuan atau perkumpulan dengan golongannya dalam satu tahun sekali, dengan maksud dan tujuan untuk membicarakan suatu adat-istiadat dari leluhurnya yang akan diajarkan kepada keturunannya. Disamping 
masalah adat-istiadat juga diajarkan tentang nilai-nilai agama dengan maksud untuk mengikat atau mengukuhkan adatnya serta untuk memberitahu garis keturunannya.

Dalam pergaulan sehari-hari interaksi yang dapat kita lihat percakapan melalui pertemuan baik secara individu dengan individu, individu dengan kelompok dan kelompok dengan kelompok. Pola interaksi antara individu dengan individu dilihat interaksi antara Lalu Yusuf dengan Lalu Kadarul. Pola interaksi antara individu dengan kelompok pertemuan antara pengelingsir (tokoh yang dituakan dalam golongan bangsawan) dengan para tokoh dibawahnya untuk membicarakan tentang adat-istiadat yang berkenaan dengan kehiduapan sehari-hari yang mengacu pada tingkat keimanan dan ketakwaan kita kepada sang pencipta. Sedangkan pola interaksi antara kelompok dengan kelompok melalui pertemuan antara murid-murid TGH. Lalu Abdul Aziz Al-Muzakki dengan murid-murid Lalu Asmarazulfa dengan maksud untuk menukar pikiran tentang ilmu yang telah dipelajari, karena bentuk pengajaran TGH. Lalu Abdul Aziz Al-Muzakki dengan Lalu Asmarazulfa ada keterkaitannya.

Dalam berinteraksi bahasa merupakan salah satu alat untuk berkomunikasi antara masyarakat yang satu dengan masyarakat yang lain. Bahasa tidak saja sekedar digunakan dengan mulut akan tetapi bisa dituangkan juga dalam bentuk tulisan, maupun isyarat, kaitannya dengan itu masayarakat bangsawan Desa Sakra dalam melakukan interaksinya menggunakan bahasa sasak. Bahasa yang digunakan oleh keturunan bangsawan (perwangse) disebut bahasa halus. Karena sejak dulu golongan bangsawan sangat menghargai dan mempertahankan etika, kesopanan dalam berbahasa sehingga masyarakat non bangsawan yang masuk ke lingkungan golongan bangsawan harus menggunakan bahasa halus (bahasa golongan bangsawan), sebaliknya yang tidak bisa sama sekali menggunakan bahasa halus maka dia kurang akrab bergaul dengan golongan bangsawan.

Bahasa halus menjadi identitas tersendiri bagi golongan bangsawan, tidak terkecuali pada bangsawan Sakra. Bahkan bahasa halus di Sakra bisa dikatakan sudah menjadi bahasa utama yang bukan hanya sebagai tanda dari identitas kelas sosial, karena banyak dari masyarakat biasa yang menguasai dengan baik bahasa halus ini, bahkan banyak digolongkan non bangsawan yang menggunakan bahasa halus walaupun secara sederhana. Dalam arti bahasa halus yang digunakan adalah bahasa halus pertengahan sesuai dengan kebutuhan percakapan sehari-hari. Bahasa golongan bangsawan ya (nggih), sudah (sampun), dan seterusnya. Sedangkan dalam bentuk percakapannya. "Ampurayan gawen 
tiang dateng, tiang tunas gadingan tambah”. Kemudian Lalu Yusuf mengambilkan tambah (cangkul) seraya berkata “Ape yak tetambah, mbe dek taok ngadu”. Lalu Kadarul pun menjawab "Tiang nambah nike bangket sengak tiang talet ambon".

\section{Pola Interaksi Masyarakat Bangsawan dengan Non Bangsawan}

Masyarakat Desa Sakra terbagi menjadi 2 (dua) kelompok yakni masyarakat golongan bangsawan dan non bangsawan. Kedua golongan masyarakat ini hidup berdampingan meski golongan bangsawan lebih cenderung agak tertutup terhadap masyarakat luar, ini diakibatkan adanya sikap feodal yang dimiliki oleh golongan bangsawan pada umumnya. Dalam interaksinya masyarakat golongan non bangsawan dituntut untuk beradaptasi dengan adat dan kebiasaan yang dimiliki golongan bangsawan, ini bisa membuktikan bahwa masyarakat non bangsawan memiliki rasa hormat terhadap golongan bangsawan. Selain itu juga biasanya dari golongan bangsawan memiliki pesuruh yang berasal dari masyarakat non bangsawan dan biasanya pesuruh ini bekerja dan selalu mentaati apapun yang diperintahkan oleh golongan bangsawan.

Meskipun terjadi hal seperti di atas masyarakat dari golongan non bangsawan tidak pernah mempermasalahkan hal tersebut, ini dikarenakan hal tersebut sudah merupakan tradisi dan merupakan tanda hormat masyarakat non bangsawan terhadap masyarakat bangsawan yang ada di Desa Sakra. Selain itu juga antara masyarakat bangsawan dan masyarakat non bangasawan tetap bekerja sama dalam menjaga kerukunan dan ketertiban di Desa Sakra.

Saat ini telah terjadi erosi kebudayaan dan hal ini tidak bisa dibantah, karena adatistiadat orang tua terdahulu seolah-olah ditelan bumi yang diganti dengan modifikasi yang sesuai dengan perkembangan zaman, walaupun dengan cara praktik banyak juga adatistiadat tersebut yang masih berlaku, khusus bagi golongan bangsawan yang dulu sangat dihormati, sampai-sampai jarang masyarakat non bangsawan berani bertemu dengan golongan bangsawan karena begitu dihormati, begitu juga dengan kebetulan bertemu di jalan harus mengucapkan salam seraya menundukkan kepalanya sebagai penghormatan.

a. Interaksi orang tua dengan orang tua

Dalam pergaulan sehari-hari, disaat bertatap muka antara Lalu Muhsin dengan Amaq Nursadi. Amaq Nursadi harus mengucapkan salam seraya menundukan kepalanya serta menanyakan "Ampurayan mekel mbe delumbar niki”. Kemudian Lalu Muhsin menjawab “Te lalo ojok bale pak kadus” lebih 
lanjut Lalu Muhhsin “Lamun side jak mbe de laik”. Amaq Nursadi ”Tiang lalo ojok bangket".

Selanjutnya percakapan antara Lalu Suparman dengan Amaq Rais saat berkunjung ke rumah Lalu Suparman. Amaq Rais mengucapkan salam dan menundukkan kepalanya semasih berada di depan pintu. Pada saat dijawab salamnya oleh Lalu Suparman, maka Amaq Rais dipersilahkan masuk. Setelah masuk Amaq Rais mengatakan "Ampurayan mekel, gawen tiang dateng, tiang matur berembe kabar pelinggih mangkin?" Lalu Suparman "Alhamdulillah sehat, lamunside berembe, ape te talet lek bangket nani?" Amaq Rais "Alhamdulillah sehat, tiang talet jagung sengak mangkin ndarak aik telabah. Sak mangkin ndek tiang talet pare, laguk tiang gentik talet jagung. Lamun pelinggih napi tetalet nike bangket?" Lalu Suparman "Lamun ite talet pare, Alhamdulillah lek bangket tetep arak aik telabah, sengak rapet kance bendungan lek pengempel, mudahan sak pade solah taletan adek sak bau te bejekat". Amaq Rais "Nggih Amiin, nunasan mekel lamun magrib napi de gawek, tiang pesilak pelinggih zikir niki bale Amaq Ida". Lalu Suparman “Ndarak, mudahan sak pade sehat, insya Allah ite dateng”. Amaq Rais "Lamun meno silak tiang pamit, sengak tiang pesilak sak lainan. Assalamu alaikum...”

b. Interaksi orang tua dengan yang lebih muda

Percakapan Baiq Yuli dengan Ana ketika bertemu di rumah Inaq Ana. Disini Baiq Yuli mengucapkan salam seraya berjabat tangan "Inak Ana arak Inak lek bale, lamun arak empohante sengak arak perlu”. Ana menjawab "Nggih mangkin tiang empohan nike lek pawon taok angke meriap”. Baiq Yuli "Aok".

c. Interaksi orang tua dengan anak

Percakapan Lalu Idris dengan Ari ketika bertemu dijalan. Pada saat bertemu Ari terlebih dahulu mengucapkan salam sambil menundukkan kepalanya seraya berkata "Mbe delumbar niki Mamik sangkerapi". Kemudian Lalu Idris menjawab "Te lalo jok Kantor Dese sengak arak pemeriksaan mate gratis kance tek tebeng kace mate lamun pengita'an wah saru, lamun kamu mbe mek laik? Ari menjawab "Tiang jok bale papuk, sengak angken sakit, silak tiang pamit Assalamu alaikum. 
Dilihat dari percakapan di atas maka termasuk pola interaksi yang bersifat demokratis, sebab antara kedua golongan ini memiliki kewenangan yang sama, akan tetapi tidak menutup kemungkinan golangan bangsawan juga bisa bersifat otoritas terhadap golonggan non bangsawan. Masyarakat bangsawan dengan non bangsawan yang mengacu pada sistem membantu (gotong royong) yang dilakukan oleh kelompok dengan kelompok terlihat pada acara roah, begawe, kematian, zikiran serta membangun rumah atau tempattempat umum. Dalam hal ini ada sebagian golongan bangsawan yang tidak ikut serta dalam acara tersebut, bukan karena pengelingsir (tokoh yang dituakan) tidak ingin ikut serta tetapi masyarakat tidak menginginkan pengelingsir untuk bekerja karena pengelingsir dihormati dan dihargai. Disini masyarakat sangat merasa bangga ketika pengelingsir datang walaupun hanya untuk melihat saja.

Dalam golongan bangsawan dalam bermasyarakat adalah untuk memberikan contoh yang baik kepada keluarganya maupun kepada golongan non bangsawan, karena dimana dalam bermasyarakat disini kita harus bisa memberikan contoh yang baik kepada keluarga, tetangga di sekitar rumah bahkan dengan masyarakat yang lain.

Dalam pola ini bisa kita lihat pada setiap tingkah laku keseharian yang dilakukan oleh golongan bangsawan terhadap non bangsawan baik dilihat dari bahasa, adat istiadat, dan sopan santun dalam bersikap terhadap semua orang. Hal inilah yang di contohkan golongan bangsawan terhadap non bangsawan, dengan demikian golongan non bangsawanpun akan mengajarkan hal tersebut terhadap keluarganya, tetangga, bahkan di masyarakat sekitarnya, sehingga mencerminkan suasana nyaman dan damai.

Ketika kita berbicara mengenai pola interaksi sosial masyarakat bangsawan dengan non bangsawan, maka sudah barang tentu terdapat beberapa hal yang membedakan dengan golongan yang lain baik di atas golongannya maupun strata yang berada di bawah golongannya. Tetapi tidak menutup kemungkinan kalau golongan bangsawan juga menghormati golongan yang lebih rendah darinya, serta begitu pula sebaliknya.

Adat-istiadat merupakan cermin dari lokal genius yang dikembangkan oleh masyarakat secara turun-temurun. Walaupun akan selalu terdapat modifikasi sesuai dengan perkembangan zaman. Masyarakat Desa Sakra yang dalam pola interaksi sosialnya terdapat dua golongan yang berbeda, di mana masing-masing dari golongannya mengikuti adatistiadat yang berlaku sesuai dengan adat-istiadat yang ditinggalkan oleh nenek monyangnya, meskipun terdapat banyak kesamaan walaupun dari golongan stratifikasi 
sosial yang berbeda, hal ini selain disebabkan kesamaan tempat tinggal secara geografi maupun persamaan-persamaan yang lain seperti agama, pola pikir dan sebagainya. Dalam hal adat-istiadat di Desa Sakra terdapat dua golongan sosial yang berbeda, maka terdapat perbedaan-perbedaan yang dapat kita identifikasi, karena akan menyangkut peraturan yang dikembangkan dalam kehidupan sehari-hari oleh masing-masing golongan.

Dari uraian di atas dapat disimpulkan bahwa adat-istiadat antara golongan bangsawan dengan non bangsawan terdapat perbedaan dilihat dari tingkah laku dalam kebiasaan sehari-hari. Dalam pergaulan sehari-hari bahasa merupakan salah satu alat untuk berkomunikasi antara masyarakat yang satu dengan masyarakat yang lain. Bahasa tidak saja sekedar digunakan dengan mulut akan tetapi bisa dituangkan juga dalam bentuk tulisan, maupun isyarat, kaitannya dengan itu masayarakat Desa Sakra dalam melakukan interaksinya menggunakan bahasa sasak, yang dimana dalam bahasa sasak ini dibedakan menjadi dua macam bahasa.

Bahasa yang digunakan oleh masyarakat Desa Sakra adalah bahasa sasak, tetapi ada perbedaan bahasa yang digunakan oleh keturunan bangsawan (perwangse) disebut bahasa halus sedangkan bahasa yang digunakan oleh keturunan non bangsawan (jajar karang), bahasa yang agak kasar. Bahasa halus ini juga dipelajari oleh golongan non bangsawan untuk menjaga etika, kesopanan dan mempermudah berkomunikasi dengan golongan non bangsawan, karena sejak dulu golongan bangsawan sangat menghargai dan mempertahankan kesopanan dalam berbahasa sehinnga masyarakat non bangsawan yang masuk ke lingkungan golongan bangsawan harus menggunakan bahasa halus (bahasa golongan bangsawan), sebaliknya yang tidak bisa sama sekali menggunakan bahasa halus maka dia kurang akrab bergaul dengan golongan bangsawan.

\section{Penutup}

Bangsawan merupakan salah satu tingkatan sosial di Desa Sakra dan sudah barang tentu keberadaannya dapat diidentifikasi dengan adanya pola interaksi. Karena perbedaan status sosial antara masyarakat bangsawan dengan non bangsawan maka bahasa dan adatistiadat banyak yang berbeda meskipun memiliki banyak kesaman secara geografis tempat tinggal di spasial yang sama, namun dalam bahasa dan adat-istiadat yang berbeda tersebut berbeda juga perwarisannya secara sistem kekerabatan dari generasi ke generasi. 
Dalam membahas tentang pola interaksi masyarakat bangsawan dengan non bangsawan di Desa Sakra. Terdapat beberapa pola interaksi sosial sedagai berikut:

1. Pola interaksi individu dengan individu

2. Pola interaksi kelompok dengan kelompok

3. Pola interaksi kelompok dengan kelompok

Pola interaksi individu dengan kelompok memiliki bentuk yang ideal yakni dijalankan oleh masyarakat bangsawan :

a. Pola lingkaran merupakan pola interaksi yang menunjukkan adanya kebebasan dari setiap anggota untuk berhubungan dengan pihak manapun dalam kelompoknya (bersifat demokratis).

b. Pola huruf $\mathrm{X}$ dan $\mathrm{Y}$ di tandai dengan terbatasnya hubungan antar kelompok sebab hubungan harus di lakukan melalui birokrasi yang kaku, tetapi mekanisme kelompok mudah terkendali karena adanya pemimpin yang dapat menguasai dan mengatur anggotanya walaupun dipaksakan (bersifat otoritas). Sedangkan pola yang dijalankan oleh masyarakat non bangsawan hanya pola lingkaran yang menunjukkan pada kebebasan dalam berhubungan dengan pihak manapun yakni dengan golongan bangsawan (bersifat demokratis).

Perkembangan bangsawan di Sakra menyisahkan kenangan sejarah tersendiri karena seperti bangsawan yang lain pernah menerapkan adat-istiadat sesuai dengan status sosial kebangsawanannya, baik dari segi bahasa, adat-istiadat, pergaulan sehari-hari dalam pewarisan dari generasi ke generasi memang tidak berjalan mulus bahkan sering terjadi perubahan sesuai dengan perkembangan zaman.

\section{Daftar Pustaka}

Budiwati, Erni. 2002. Islam Sasak. Yogyakarta: LKIS.

Bungin, Burhan. 2008. Penulisan Kualitatif. Jakarta: Kencana.

Depak. RI. 2010. Al-Qur'an dan Terjemahnya. Bogor: Lembaga Percetakan Al-Qur'an Kementerian Agama RI.

Depdikbud. 1959. Ensiklopedi Indonesia Edisi Kedua. Jakarta: Ichtiar Baru-Van Hoeve. Depdiknas. 2007. Kamus Besar Bahasa Indonesia edisi kedua, Jakarta: Balai Pustaka.

Gottschalk, Louis. 2008. Mengerti sajarah. Jakarta: UI-Press.

Koentjaraningrat. 1996. Pengantar Antropologi 1. Jakarta: Rineka Cipta.

2003. Pengantar Antropologi 1. Jakarta: Rineka Cipta.

2009. Pengantar Ilmu Antropologi. Jakarta: Rineka Cipta. 
Pola Interaksi Masyarakat Bangsawan.......Srianti

Lexy J. Moleong. 2005. Metodologi Penulisan Kualitatif. Bandung: Remaja Rosdakarya.

2009. Metodologi Penulisan Kualitatif. Bandung: Remaja

Rosdakarya.

Rajasa, Sutan. 2002. Kamus Ilmiah Populer. Surabaya: Karya Utama.

Soerjono, Soekanto. 2012. Sosiologi Suatu Pengantar. Jakarta: Grapindo Persada.

Soyomukti, Nurani. 2010. Pengantar Sosiologi. Yogyakarta: Ar-Ruzz Media.

Sugiyono. 2008. Metode Penelitian Kuantitatif Kualitatif dan R\&D. Bandung: Alfabeta. 2010. Metode Penelitian Kuantitatif Kualitatif dan R\&D. Bandung: Alfabeta.

Webber, Max. 1960. Manifesto Partai Komunis. Jakarta: Nalar.

Widjaya. 1985. Individu, Keluarga dan Masyarakat. Palembang: Akademika Presindo. 